\title{
BEBIDA LÁCTEA COM AMARANTO
}

Ana Paula Masson ${ }^{1}$

Otavio José Viganó

\begin{abstract}
RESUMO
O soro de leite é um resíduo da produção de queijos e, muitas vezes, um problema para os laticínios, pois apresenta potencial poluidor. A utilização do soro de leite em bebidas lácteas se apresenta como uma alternativa para aproveitar o potencial nutritivo deste resíduo. O amaranto é um pseudocereal pouco conhecido no Brasil, no entanto, apresenta proteínas de alto valor biológico. O objetivo deste trabalho foi desenvolver uma bebida láctea com amaranto sabor chocolate branco, em três formulações diferentes: pasteurizada, acidificada e fermentada, realizando a caracterização físicoquímica, análise sensorial e determinação da vida de prateleira. O teor de proteínas das três formulações ficou acima de $2,5 \%$, sendo maior do que o normalmente encontrado em bebidas lácteas; os demais parâmetros físico-químicos ficaram dentro do esperado. $\mathrm{Na}$ análise sensorial, a bebida láctea pasteurizada apresentou mais de $97 \%$ de avaliações positivas, quando a acidificada apresentou $88 \%$ e a fermentada $84 \%$; os provadores apresentaram boa aceitação pela adição do amaranto e o sabor de chocolate branco. A vida de prateleira demonstrou a estabilidade nos 35 dias de armazenamento da bebida acidificada e da fermentada, enquanto que apenas a pasteurizada apresentou durabilidade de 7 dias, sendo que o teor proteico foi aumentado devido a adição do amaranto e considerando-se que a formulação mais aceita foi a pasteurizada e que a mesma apresentou baixa estabilidade no armazenamento, recomenda-se a utilização do processo UAT para a elaboração deste produto.
\end{abstract}

Palavras-chave: Soro de leite. Pseudocereal. Teor proteico.

${ }^{1}$ Especialista, e-mail: ana.masson@sc.senai.br

${ }^{2}$ Graduado, e-mail: otavio.vigano@sc.senai.br 


\section{INTRODUÇÃO}

O amaranto é considerado um pseudocereal, pois não pertence à família das gramíneas, o que o descaracteriza como cereal, mas sua forma de consumo é muito semelhante, por isso considera-se como pseudocereal, ou seja, falso cereal. Desde a Antiguidade essa semente é cultivada em diversos lugares do mundo e, atualmente, é cultivada, da Argentina ao Sudoeste dos Estados Unidos, da Pérsia ao Ceilão, da Índia ao Himalaia, do Interior da China à Mongolia e África do Oriental (SAUER, 1950 apud AMAYA-FRAFAN, MARCÍLIO e SPEHAR, 2005).

No Brasil, ainda é pouco cultivado e conhecido, no entanto, estudos realizados pela Empresa Brasileira de Pesquisa Agropecuária (EMBRAPA), principalmente na região do Cerrado, apresentaram potencial viável de produção (SANTOS; COSTA, 2007). A importância do consumo do amaranto está relacionada às suas características nutricionais, já que apresenta aminoácidos essenciais, sendo considerado de alto valor biológico, comparável às proteínas de origem cárnea.

A produção de queijos tem como resíduo o soro do leite, que é constituído, principalmente, por água e material orgânico, o qual é potencial poluidor, não podendo ser descartado no ambiente antes de receber correto tratamento. Dessa forma, o soro nas queijarias se tornou um problema a ser resolvido, tendo sido destinado a tratamento de efluentes ou então utilizado em outras formulações em que se permite a sua adição, podendo, assim, além de não prejudicar o meio ambiente, aproveitar os nutrientes que ainda estão presentes no soro.

As bebidas lácteas são alternativas apresentadas pela indústria para utilização de soro de leite, com consequente redução de custo de produção, sendo permitida esta utilização pela legislação brasileira neste tipo de produto. A produção das bebidas lácteas vem ganhando força junto ao mercado consumidor devido ao seu menor custo e ao sabor cada vez melhor e diferenciado, apresentados pelas indústrias fabricantes, que tem procurado inovar e oferecer produtos de elevada qualidade.

Dentro desse contexto, o presente trabalho teve por finalidade desenvolver uma bebida láctea para o Laticínio Santa Bárbara, pequena queijaria localizada em Lacerdópolis Santa Catarina (SC), para aproveitamento do soro de leite e elaboração de um produto diferenciado para seus consumidores. A bebida láctea foi complementada com o pseudocereal amaranto para complementação de seu potencial nutritivo, e o sabor pesquisado foi o de chocolate branco a, pedido da empresa.

\subsection{Objetivo Geral}

Desenvolver bebida láctea sabor chocolate branco utilizando soro de leite e o pseudocereal amaranto. 


\subsection{Objetivos Específicos}
a) Produzir uma bebida láctea com a utilização do pseudocereal amaranto;
b) Caracterizar a bebida láctea por meio de análises físico-químicas;
c) Analisar sensorialmente o produto para avaliação de sua aceitabilidade perante os consumidores;
d) Determinar a vida de prateleira da bebida láctea.

\section{DESENVOLVIMENTO}

\subsection{Revisão da Literatura}

\subsubsection{Bebida Láctea}

De acordo com a Instrução Normativa no 16, de 23 de agosto de 2005, entende-se por bebida láctea o produto lácteo resultante da mistura do leite e soro de leite adicionado ou não de produtos ou substâncias alimentícias, gordura vegetal, leite fermentado, fermentos lácteos e outros produtos lácteos. Ainda, segundo a mesma legislação, a base láctea da bebida láctea deve representar pelo menos 51\% massa/massa do total de ingredientes do produto (BRASIL, 2005).

Dependendo do tratamento térmico, fermentação e adição de outras substâncias alimentícias, as bebida lácteas são classificadas como pasteurizadas, esterilizadas ou UHT, fermentadas ou não fermentadas, com ou sem adição (BRASIL, 2005).

As bebidas lácteas foram desenvolvidas objetivando atrair o consumidor que apresenta um menor poder aquisitivo, já que as mesmas são produzidas com menor custo. A princípio, as bebidas lácteas eram vendidas para atender os serviços de alimentação catering e a merenda escolar. A grande procura do consumidor por novos produtos culminou no aumento significativo de participação de mercado desses produtos (OLIVEIRA, 2009).

A produção de bebidas lácteas tem aumentado e ganhou popularidade em virtude da maior procura pelos consumidores por produtos inovadores, saudáveis, seguros e práticos para o consumo, aliando-se com a consolidação de mercado dos produtos (THAMER; PENNA, 2006).

A diferenciação entre bebida láctea e iogurte é que a primeira é mais líquida, enquanto o segundo é mais rico em sólidos totais. Isso se deve ao fato de que na bebida láctea existe a incorporação de soro de leite, enquanto que no iogurte a base é a utilização do leite (THAMER; PENNA, 2006). 
O paladar brasileiro se adaptou melhor às bebidas lácteas com baixo grau de acidez, sendo considerada uma grande descoberta. O aumento do mercado de iogurtes devido à inserção no comércio desse produto foi de aproximadamente 17\% (OLIVEIRA, 2009).

Encontram-se muitas pesquisas relatando a utilização de soro de queijo para o desenvolvimento de bebidas lácteas. Santos et. al (2008) estudaram a influência da concentração de soro na aceitação sensorial de bebida láctea fermentada com polpa de manga. Kempeka et al. (2008) estudaram a formulação de bebida láctea fermentada sabor pêssego utilizando substratos alternativos e cultura probiótica. Fontan (2008) pesquisou a influência do uso de espessantes nas características sensoriais e físicoquímicas de bebida láctea com polpa de umbu.

\subsubsection{Soro de Leite}

De maneira bem simples, o leite é a secreção mamária de mamíferos (TRONCO, 2010). Conforme o Regulamento de Inspeção Industrial e Sanitária de Produtos de Origem Animal (RIISPOA), o artigo 475 denomina o leite sem outra especificação, o produto normal, fresco, integral, oriundo da ordenha completa e ininterrupta de vacas sadias (BRASIL, 1980).

A composição do leite é aproximada e varia de acordo com a estação do ano, e ainda com a diferença entre raças, além dos estágios de lactação e do sistema de alimentação do animal. Em média, apresenta 4,0\% de gordura, 3,5\% de proteína, 4,8\% de lactose e $0,7 \%$ de sais, o restante é constituído de água (ANTUNES, 2003).

O soro apresenta propriedades funcionais e bioativas devido a seus componentes, com destaque para as proteínas, sendo alfa-lactoalbumina, e beta-lactoglobulina. A albumina sérica bovina e a lactoperoxidase são as principais proteínas do soro. Atribuem-se a estes componentes atividades anti-câncer, hipocolesterolêmica, anti-inflamatória, de proteção e reparação das células entéricas, antiulcerogênica, entre outras. Além disso, o soro de leite possui minerais importantes como o cálcio, fósforo e magnésio, componentes que estão em pequenas quantidades na alimentação de grande parte da população, podendo ocasionar predisposição a determinadas doenças, como a hipertensão (ZACARCHENCO et al., 2008).

As proteínas do leite são distribuídas em três classes: (1) caseínas; (2) proteínas do soro, incluindo enzimas e proteínas em pequenas quantidades; (3) proteínas que estão associadas à fase gordurosa ou lipídica, compondo a membrana do glóbulo de gordura do leite (ANTUNES, 2003).

A separação das caseínas do leite pode ocorrer na produção de queijos ou na fabricação de caseína, que origina as proteínas do soro. Em alguns momentos também são chamadas de proteínas do soro de queijo, no entanto, o mais adequado seria denominar de proteínas do soro de leite, já que são oriundas do leite e não do queijo. Estas podem originar vários produtos, sendo definidas como proteínas que permanecem no soro depois de ocorrida a coagulação das caseínas (ANTUNES, 2003). 
No Brasil, na maior parte das empresas fabricantes de queijo, o soro de leite, o qual consiste no resíduo gerado na produção de queijos, é simplesmente lançado nos esgotos e mananciais ou, em alguns casos, utilizado como alimento para animais. Além do impacto ambiental gerado em termos de poluição, deixa-se de empregar um produto nobre em aplicações que lhe agregariam maior valor comercial (ANTUNES, 2003).

A conversão do soro do leite em bebidas lácteas nos laticínios é uma das alternativas mais atrativas para utilizar este componente para o consumo humano, devido ao processo ser simples, sendo utilizados os mesmos equipamentos do beneficiamento do leite, além do aproveitamento das excelentes propriedades das proteínas do soro (GANDHI; PATEL, 1994, tradução nossa).

\subsubsection{Amaranto}

O gênero Amaranthus abrange diversas espécies de plantas dicotiledôneas, nas quais as folhas e sementes são consumidas na alimentação de diversos países, porém o Brasil não está incluso. Este alimento é cultivado na América ainda antes da chegada dos espanhóis, alcançando a sua melhor fase nos períodos Maia, Asteca e Inca, sendo até considerado um alimento sagrado (AMAYA-FRAFAN, MARCíLIO e SPEHAR, 2005).

Pesquisas recentes relatam a importância do consumo do pseudocereal amaranto, que apresenta, além da propriedade funcional de fibras dietéticas, normalmente encontradas nos cereais, uma qualidade proteica superior a todos os outros em aminoácidos essenciais ao organismo humano. Aminoácidos essenciais são aqueles que o corpo não consegue sintetizar em suas reações metabólicas, sendo necessária a sua adição via alimentação (LUPATINI, 2009).

O amaranto (Amaranthus cruentus) apresenta comparável potencial nutritivo, pois sua semente possui aproximadamente $15 \%$ de proteínas, com qualidade biológica superior a outros vegetais, como a soja e o feijão e comparáveis à do leite. Esse pseudocereal é rico em fibras e fonte de zinco, fósforo e cálcio (LUPATINI, 2009). A proteína presente no amaranto é considerada de alto valor biológico devido a seu conteúdo de lisina, aproximadamente 5\%;na proteína também há $4,4 \%$ de aminoácidos sulfurados. Estes grupos de aminoácidos são os mais limitantes nos grãos em geral (AMAYA-FRAFAN, MARCÍLIO e SPEHAR, 2005).

Pesquisas com o amaranto demonstram a capacidade do mesmo no auxílio da redução dos níveis plasmáticos de colesterol. A Academia de Ciências dos Estados Unidos inseriu o amaranto na seleta lista das 36 culturas mais promissoras para eliminação da fome do mundo (LUPATINI, 2009).

Existe um interesse reconhecido por órgãos internacionais no aproveitamento do amaranto, sendo necessária, para sua utilização em maior escala, a criação de produtos de aceitabilidade geral, viabilizando a sua incorporação na alimentação humana. Europa, Estados Unidos, Canadá e Japão já despertaram interesse por este pseudocereal devido a suas propriedades nutricionais e de saúde (AMAYA-FRAFAN, MARCÍLIO e SPEHAR, 2005). 
Em estudo realizado por Santos et al (2007) sobre as vantagens do cultivo do amaranto, discutiu-se que o mesmo apresenta potencial de viabilidade de produção no Nordeste brasileiro, pois a cultura adapta-se bem às condições climáticas mais secas. Dessa forma, percebe-se que o Brasil é um potencial produtor de amaranto.

\subsubsection{Materiais e Métodos}

O experimento foi realizado no Serviço Nacional de Aprendizagem Nacional (SENAI) Unidade de Capinzal, nos laboratórios de Processamento de Alimentos, Microbiologia e Físico-químico.

\subsection{Materiais e Métodos}

\subsubsection{Material}

\section{Soro de queijo e leite}

Foi utilizado o soro de leite doce, obtido do processo de fabricação de queijos do Laticínio Santa Bárbara, localizado no município de Lacerdópolis - SC. Este foi imediatamente resfriado e transportado, sendo utilizado no mesmo dia para a elaboração da bebida láctea.

O leite utilizado no produto era de boa qualidade e também foi fornecido pela mesma empresa, tendo sido pasteurizado e resfriado para o transporte.

\section{Pseudo cereal amaranto}

O amaranto foi adquirido no município de Capinzal-SC, em loja de comércio especializada em produtos naturais.

\section{Ingredientes e aditivos}

Para a elaboração da bebida láctea, foram utilizados os seguintes ingredientes:

a) açúcar refinado e açúcar de baunilha, obtidos no comércio local;

b) o estabilizante LAC 8174-6, composto por amido modificado, espessante gelatina e estabilizante pectina, fornecido pela empresa Globalfood;

c) o fermento lácteo DELVO-YOG FVV-21 DSL, que apresenta os micro-organismos Streptococcus thermophilus e Lactobacillus delbrueckii spp bulcaricus, também fornecido pela Globafood; 
d) ácido Cítrico P.A., fornecido pela empresa Doremus;

e) conservante sorbato de potássio, também fornecido pela Doremus;

f) aroma idêntico ao natural sabor chocolate branco, adquirido da empresa Duas Rodas.

\subsubsection{Procedimentos Metodológicos}

\section{Desenvolvimento da formulação da bebida láctea com a utilização do pseudocereal amaranto}

Inicialmente, pesquisaram-se em mercados bebidas lácteas e iogurtes comercializados, a fim de identificar os ingredientes utilizados na elaboração dos mesmos, a embalagem utilizada e processamento, ou seja, se eram fermentados, pasteurizados ou UAT. Esta pesquisa objetivou a obtenção de uma base para iniciar a formulação do produto.

Também foram realizados testes de escoamento em produtos similares de mercado, utilizando o viscosímetro copo Ford, que normalmente é utilizado para a determinação de viscosidade de tintas e cremes. Para o teste um volume constante foi adicionado no reservatório do copo e, por meio de um orifício de tamanho fixo, o líquido escoou determinando, assim, o tempo que o líquido levou para esvaziar completamente o copo.

O teste teve por objetivo verificar a viscosidade ideal para a bebida a ser desenvolvida. Os produtos similares comerciais testados foram bebidas lácteas fermentadas sabor morango e bebidas lácteas achocolatadas. A figura 1 apresenta o equipamento Copo Ford utilizado para o teste.

Figura 1: Viscosímetro copo Ford

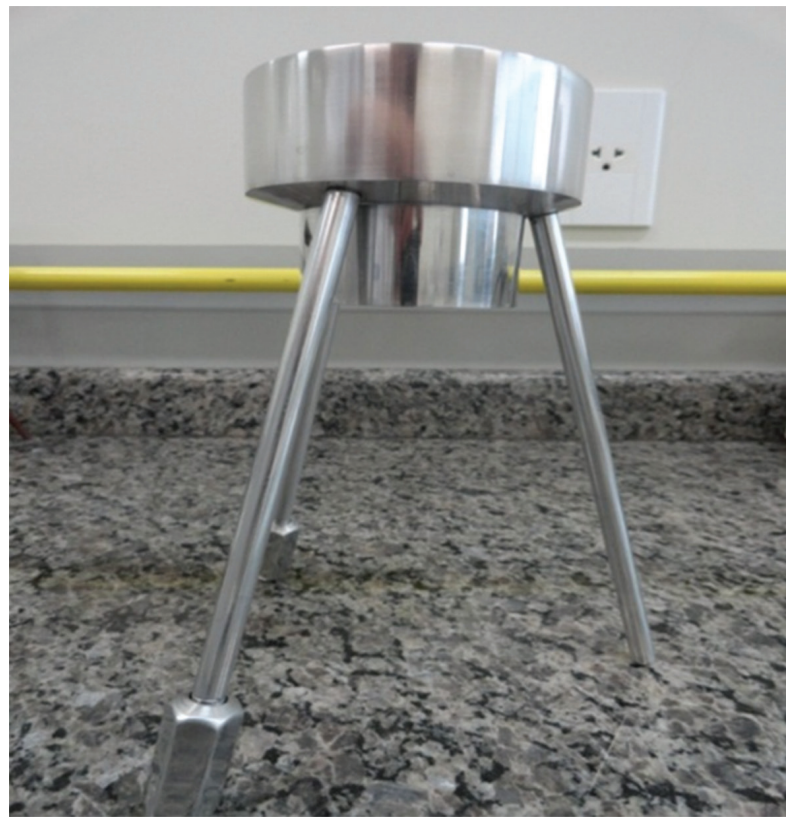

Fonte: Dos autores 
Foram realizados testes de formulações com diferentes concentrações de açúcar, aromas e amaranto. A cada teste os próprios pesquisadores provavam o produto e definiam alterações. Como a empresa interessada na bebida láctea ainda não apresentava definição de produto desejado, foram definidos três processos diferentes para avaliação da aceitação pelo consumidor.

Os produtos desenvolvidos foram:

a) bebida láctea sabor chocolate branco com amaranto pasteurizada;

b) bebida láctea sabor chocolate branco com amaranto pasteurizada e acidificada;

c) bebida láctea fermentada sabor chocolate branco com amaranto.

Nas três formulações utilizou-se $50 \%$ de soro de leite e as mesmas proporções de leite, açúcar refinado e açúcar de baunilha, assim como de estabilizante, sorbato de potássio e aroma idêntico ao natural sabor de chocolate branco, conforme instruções dos fabricantes. Diferentemente dos produtos $\mathbf{a}$ e $\mathbf{b}$, no produto c elaborou-se uma calda separadamente para incorporação no produto após a fermentação, sendo o conservante adicionado nesta calda. Em todos os casos a adição do amaranto foi na proporção de $2 \%$ em relação ao total da formulação, e no produto c o mesmo foi adicionado na calda.

Para a elaboração das formulações $\mathbf{a}$ e $\mathbf{b}$, o soro foi aquecido a $65^{\circ} \mathrm{C}$ para a inativação do coalho. Como o soro é proveniente da produção de queijos, pode existir atividade residual da enzima coagulante, o que poderia interferir no processo. Os ingredientes sólidos (açúcares, estabilizante, conservante e amaranto) foram misturados em liquidificador, juntamente com parte do leite facilitando a dissolução dos mesmos.

A mistura liquidificada foi adicionada ao soro aquecido e tratada termicamente a $90 \circ \mathrm{C}$ por 10 minutos, e após resfriada a 25 으 dividindo-se em duas partes. A primeira parte foi envasada em copos e mantida refrigerada; a segunda parte teve o $\mathrm{pH}$ ajustado para 4,0 a 4,5 com ácido cítrico $(50 \% \mathrm{~m} / \mathrm{v})$, sendo envasado e também mantido sob refrigeração. Obteve-se, dessa forma, as bebidas lácteas a e b. O fluxograma ilustrado a seguir resume os procedimentos adotados na elaboração das fórmulas. 
Figura 2: Fluxograma Elaboração da bebida láctea a e b

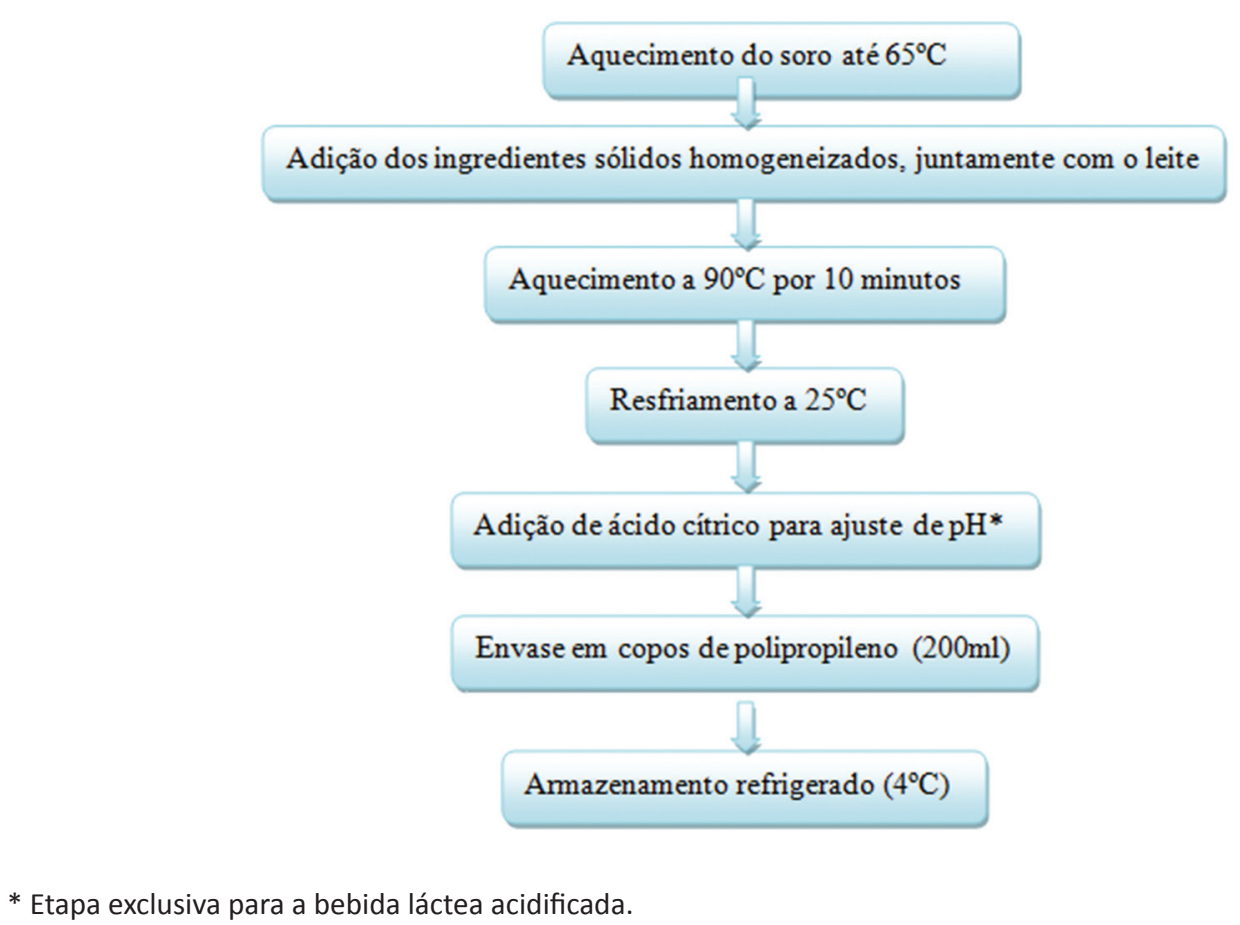

Fonte: Dos autores

Para a elaboração da bebida fermentada, utilizou-se a mesma proporção dos ingredientes dos demais produtos, apenas diferenciando a elaboração da calda como anteriormente citado. $O$ soro foi aquecido até 65 으, adicionando-se os ingredientes sólidos (estabilizante e metade do açúcar refinado) já liquidificados com o leite. Em seguida, realizou-se o tratamento térmico a $90 \circ \mathrm{C}$, por 10 minutos, resfriando-se a $42^{\circ} \mathrm{C}$ para a adição da cultura láctea, de acordo com a recomendação do fabricante. O produto foi fermentado até acidez de 68 a $72 \circ \mathrm{D}$, sendo resfriado a $16 \circ \mathrm{O}$.

Preparou-se a calda separadamente com açúcar, açúcar de baunilha, amaranto, aroma e leite, aquecendo a $90 \circ \mathrm{C}$ por 5 minutos, resfriando-se a $16 \circ \mathrm{C}$ e adicionando-se ao produto fermentado, realizando a homogeneização cuidadosamente. O envase foi realizado em copos de polipropileno, sendo armazenado e refrigerado a 4 으. O Fluxograma a seguir apresenta a elaboração da bebida láctea fermentada. 
Figura 3: Fluxograma Elaboração da bebida láctea c

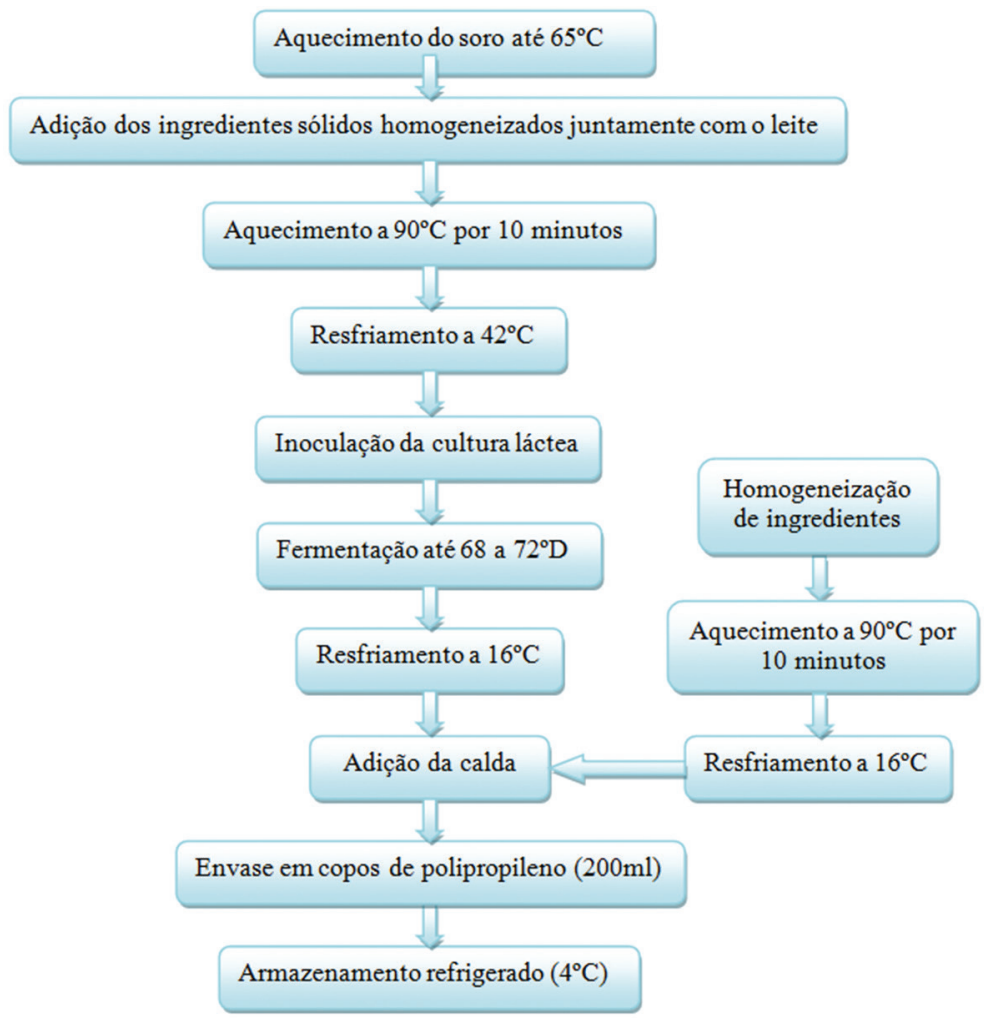

Fonte: Dos autores

\section{Caracterização da bebida láctea por meio de análises físico-químicas}

As três formulações de bebidas desenvolvidas foram caracterizadas em relação aos seguintes parâmetros físico-químicos:

a) $\mathrm{pH}: \mathrm{o} \mathrm{pH}$ das amostras foi determinado utilizando um pHmetro de bancada marca LS Logen Scientific (Modelo LS 300-3), sendo calibrado com soluções tampão pH4,00 e pH 7,00;

b) Acidez titulável: este parâmetro foi analisado de acordo com a metodologia do Ministério da Agricultura Pecuária e Abastecimento (MAPA) (BRASIL, 2006). Os resultados foram expressos em gramas de ácido lático por $100 \mathrm{ml}$;

c) Proteínas: a determinação de proteínas foi realizada pelo método de Kjedahl, de acordo com a metodologia do MAPA (BRASIL, 2006). O fator para determinação de proteínas utilizado foi de 6,25 , correspondente às proteínas solúveis do leite; 
d) Umidade: a umidade foi determinada pelo método de secagem em estufa, segundo a metodologia do MAPA (BRASIL, 2006);

e) Cinzas: o teor de cinzas foi determinado utilizando-se a mufla; de acordo com a metodologia do MAPA (BRASIL, 2006);

f) Teor de lipídios: a determinação de gordura foi realizada pelo método de Gerber, seguindo a metodologia do MAPA (BRASIL, 2006);

g) Sólidos solúveis: esta determinação foi realizada utilizando-se um refratômetro portátil manual da Biosystens (Modelo 107), com três escalas de 0 a $90 \%$, sendo utilizada a escala 1 de 0 a $42 \%$.

\section{Análise sensorial do produto para avaliação de sua aceitabilidade}

Testes de aceitação avaliam quanto o consumidor gosta ou desgosta de um produto, sendo este classificado como um método sensorial afetivo.

Aplicou-se um teste de aceitação conhecido como teste hedônico, utilizando-se uma escala hedônica facial de cinco pontos. Foram realizados testes em supermercados da região Meio Oeste de Santa Catarina, e no evento Mundo SENAI, promovido na Unidade de Capinzal - SC.

Os provadores receberam uma amostra codificada, juntamente com a ficha de avaliação, assinalando o item que melhor descrevesse a sua opinião sobre o produto (Quadro 1).

Quadro 1: Ficha de avaliação

Prove o produto e marque um $\mathrm{X}$ no quadrado da figura abaixo que melhor descreve a sua opinião sobre o produto.

Código:

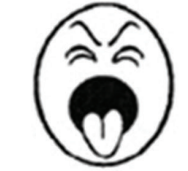

DESGOSTEI MUITO

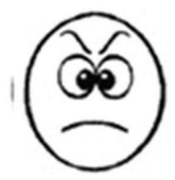

DESGOSTEI

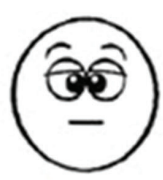

NEM GOSTEI NEM DESGOITE

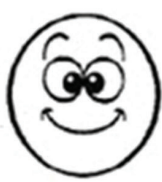

GOSTEI

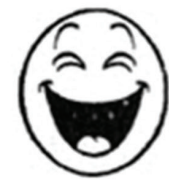

GOSTEI MUITO

Comentários:

Fonte: Dos autores 
Para a estratificação dos dados, as fichas preenchidas foram organizadas e as avaliações enumeradas de 1 a 5. Para a análise dos resultados realizou-se o cálculo do percentual de avaliações para cada opção marcada, apresentando-se os dados em histograma, comparando-se a porcentagem de avaliações positivas para cada tratamento.

\section{Determinação da vida de prateleira da bebida láctea}

Realizou-se a determinação da vida de prateleira do produto das três formulações testadas. Foram realizadas três repetições, sendo que cada repetição correspondia a um dia de processamento. Os resultados obtidos nas análises microbiológicas foram comparados com os padrões legais estipulados pela legislação específica para bebidas lácteas (BRASIL, 2005).

Foram retiradas amostras, ao acaso, nos tempos 1 dia, 7 dias, 14 dias, 21 dias e 35 dias de armazenamento, realizando-se análises físico-químicas de $\mathrm{pH}$ e acidez titulável conforme itens 3.2.2. As análises microbiológicas realizadas seguiram a metodologia do MAPA (BRASIL, 2003):

a) Aeróbios mesófilos e facultativos viáveis: para a determinação de microorganismos aeróbios mesófilos e facultativos viáveis foi utilizada a técnica de plaqueamento em Ágar Padrão com incubação das placas invertidas a 37으 por 48 horas. Para as análises foram utilizadas diluições 10-1, 10-2, 10-3 e 10-4. 0 resultado foi expresso em Unidades Formadoras de Colônias por mililitro (UFC) $\mathrm{mL})$.

b) Coliformes a 35C e 45C: a técnica utilizada para a determinação de coliformes totais (35C) e coliformes fecais ou termotolerantes (45으) foi a do Número Mais Provável (NMP). As amostras foram inoculadas em caldo Lauril Sulfato de Sódio, para teste presuntivo, sendo incubadas a 37 으 por 48 horas. As provas positivas foram repicadas para tubos com meio de cultura Caldo Verde Bile Brilhante e Caldo EC, a fim de realizar testes confirmativos. O primeiro caldo confirmou a determinação de Coliformes Totais, e o segundo, de Coliformes Fecais. Foram utilizadas três séries de três tubos das diluições 100, 10-1 e 10-2. O resultado foi expresso em NMP/mL.

c) Bolores e leveduras: os bolores e leveduras foram determinados utilizando a técnica de plaqueamento em superfície com Ágar batata dextrose acidificado com ácido tartárico. Utilizaram-se amostras nas diluições 10-1, 10-2, 10-3 e as placas foram incubadas a $25 \circ \mathrm{C}$ por 5 dias, conforme descrito na metodologia do MAPA (BRASIL, 2003). O resultado foi expresso em Unidades Formadoras de Colônias por mililitro (UFC/mL). 


\subsection{Resultados}

\subsubsection{Caracterização da bebida láctea por meio de análises físico-químicas}

As análises físico-químicas ajudaram na verificação da qualidade das amostras e foram realizadas logo após a produção. Cada uma delas tem sua importância e serve como parâmetro para avaliar as reais condições dos produtos.

Observa-se no Quadro 2 que o $\mathrm{pH}$ do tratamento a ficou próximo ao $\mathrm{pH}$ característico do leite, já que neste produto não ocorreu acidificação e nem processo fermentativo, sendo esperando neste caso, que não ocorram mudanças no $\mathrm{pH}$. No caso do tratamento b, o pH foi ajustado para 4,00 por se tratar de um produto acidificado. No caso c este parâmetro foi alterado pelo processo fermentativo, sendo desejável um pH entre 4,5 e 4,7. As considerações realizadas para o pH são as mesmas para a acidez Dornic, pois no produto b ocorreu acidificação, e no c fermentação, fatores que alteram o pH e a acidez, enquanto que no produto a não foram realizados nenhum destes processos.

Quadro 2: Caracterização físico-química das formulações de bebida láctea

\begin{tabular}{|l|l|l|l|l|l|l|l|}
\hline Produtos & pH & $\begin{array}{l}\text { Acidez } \\
\text { (oD) }\end{array}$ & $\begin{array}{l}\text { Sólidos } \\
\text { totais } \\
\text { ('Brix) }\end{array}$ & $\begin{array}{l}\text { Cinzas } \\
\text { (\%) }\end{array}$ & $\begin{array}{l}\text { Umidade } \\
\text { (\%) }\end{array}$ & $\begin{array}{l}\text { Lipídeos } \\
\text { (\%) }\end{array}$ & $\begin{array}{l}\text { Proteínas } \\
\text { (\%) }\end{array}$ \\
\hline a & 6,65 & 0,18 & 19 & 0,45 & 78,43 & 1,73 & 2,56 \\
b & 4,01 & 0,76 & 19 & 0,41 & 79,60 & 1,49 & 2,63 \\
c & 4,72 & 0,72 & 20 & 0,46 & 80,39 & 1,67 & 2,61 \\
\hline
\end{tabular}

Legenda:

a) bebida láctea sabor chocolate branco com amaranto pasteurizada;

b) bebida láctea sabor chocolate branco com amaranto pasteurizada e acidificada;

c) bebida láctea fermentada sabor chocolate branco com amaranto.

Fonte: Do autor

Como se pode verificar, as três formulações testadas apresentaram resultados muito próximos em todas as demais análises realizadas. A legislação preconiza que as bebidas lácteas apresentem no mínimo $1 \%$ de proteínas de origem láctea (BRASIL, 2005). As três amostras testadas apresentaram valor superior a 2,5\%, significando mais do que o dobro estabelecido pela legislação brasileira no total de proteínas. Isso demonstra que a adição do amaranto nas formulações trouxe um incremento proteico ao produto. As outras análises tiveram resultados satisfatórios e bem próximos das bebidas lácteas em geral. 
O conteúdo de proteínas no produto não é significativo apenas em quantidade, mas também em qualidade, pois o amaranto apresenta proteínas de alto valor biológico, muito importantes na alimentação humana, devido a seu balanço de aminoácidos, especialmente os níveis de lisina e metionina, os quais são limitados nos cereais.

Optou-se pela adição de $2 \%$ de amaranto nas formulações, pois em testes com quantidade maiores percebeu-se que ocorreu grande influência na vicosidade, já que o amaranto apresenta amido, componente que possui propriedade espessante, não ficando adequado para o produto pretendido. Assim como, quantidades menores do que $2 \%$ não ficavam muitos perceptíveis no produto e também não influenciariam significativamente no teor proteico.

\subsubsection{Análise sensorial do produto para avaliação de sua aceitabilidade}

A formulação a, produto apenas pasteurizado, foi a que mais agradou aos provadores, apresentando aproximadamente $97 \%$ das avaliações positivas, ou seja, pontuação 4 e 5 na escala hedônica apresentada no Quadro 1. Com aproximadamente $88 \%$ das avaliações positivas, a segunda formulação preferida foi a acidificada, tratamento $b$, seguido pelo produto fermentado, com 84\%, conforme histograma apresentado no Gráfico 1.

Gráfico 1: Porcentagem de avaliações por pontuação

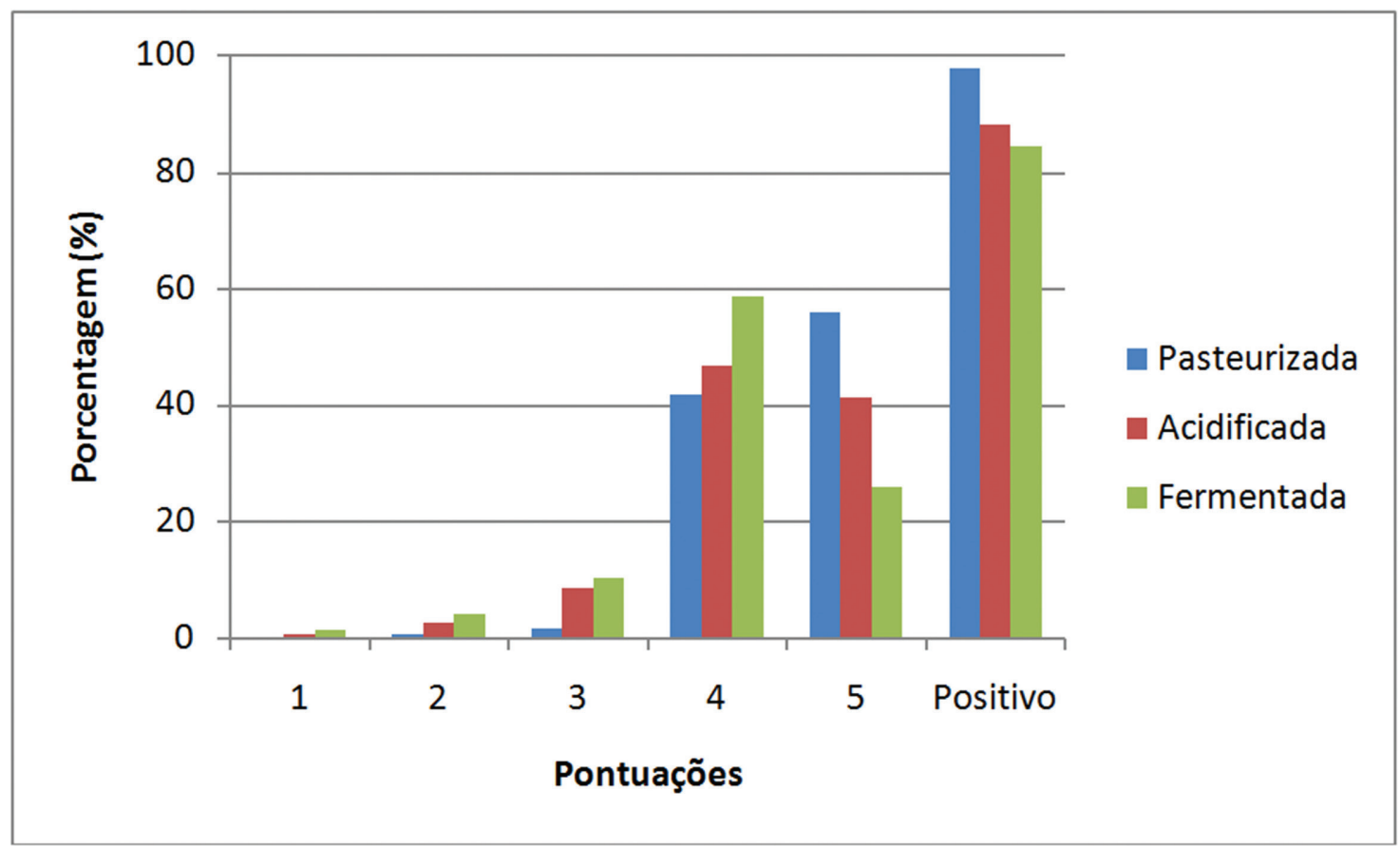

Fonte: Dos autores 
Percebeu-se que, no geral, todos os tratamentos apresentaram boa aceitação pelos consumidores, porém os produtos b e c, devido ao menor $\mathrm{pH}$ e acidez, foram os menos preferidos em comparação com o produto a, apenas pasteurizado, que apresentou a melhor pontuação entre as três formulações. Desse modo, percebe-se que o $\mathrm{pH}$ e a acidez interferiram na aceitação pelo consumidor e também tornaram o produto mais viscoso, parecido com iogurte, enquanto que o tratamento sem modificação desses fatores ficou mais líquido e mais próximo das características apresentadas pelas bebidas lácteas já comercializadas.

O sabor chocolate branco e a complementação com amaranto foi bem aceito pelos consumidores, sendo destacados em comentários realizados durante as análises sensoriais.

\subsubsection{Determinação da vida de prateleira da bebida láctea}

A vida de prateleira dos produtos foi avaliada nas três formulações propostas durante 35 dias, com três repetições. No Gráfico 2 estão apresentados os resultados da análise de mesófilos aeróbios que, neste caso, apenas foi comparado apenas para os tratamentos a e $b$, pois no tratamento c ocorreu o processo fermentativo, apresentando ao final uma contagem de 5,1 x $106 \mathrm{UFC} / \mathrm{ml}$, mantendo-se este resultado durante todo o período de análise, atendendo ao mínimo exigido pela legislação, que é de $106 \mathrm{UFC} / \mathrm{ml}$.

Gráfico 2: Crescimento microbiológico de mesófilos aeróbios, durante os 35 dias de armazenamento

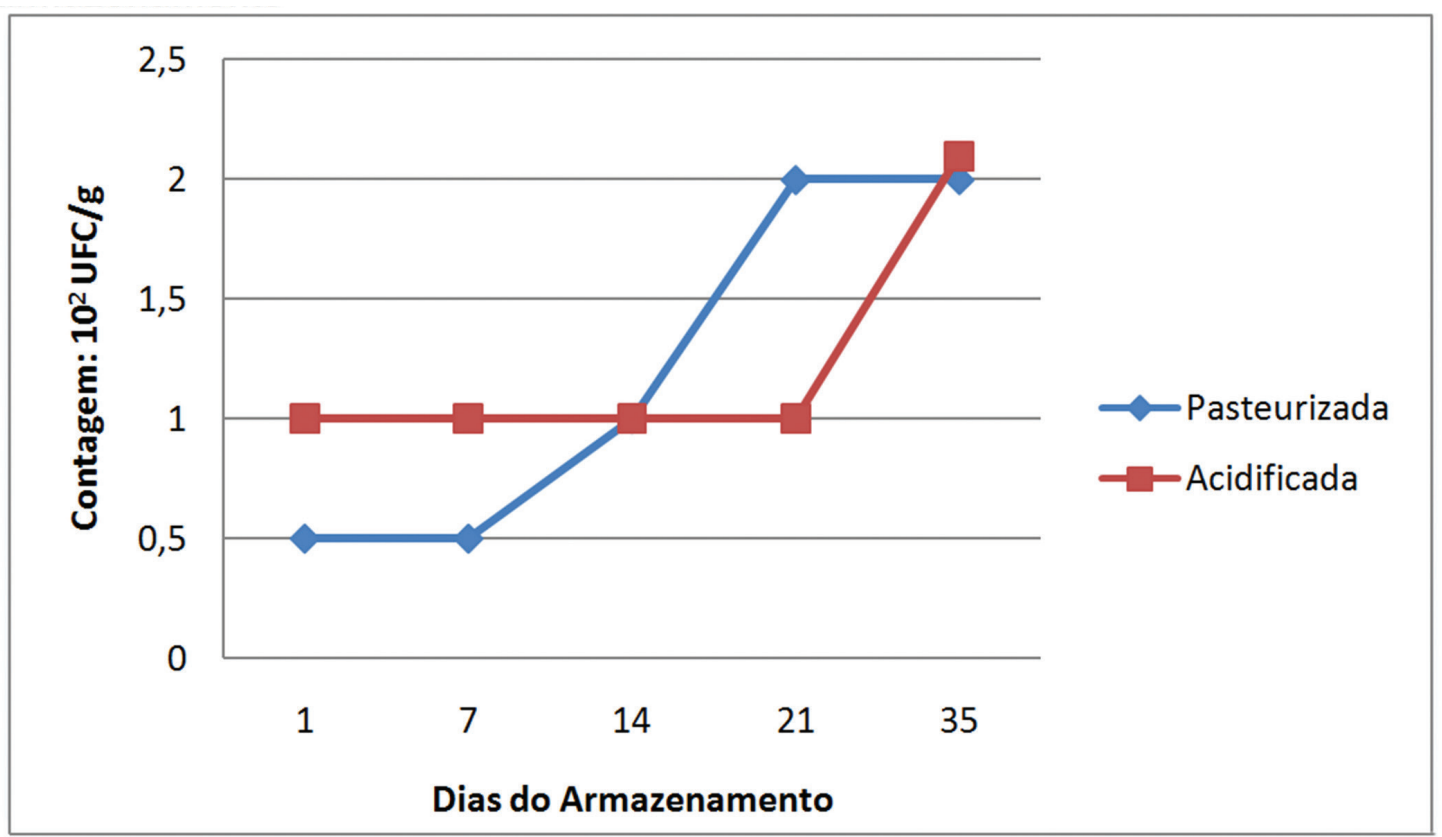

Fonte: Dos autores 
A contagem de mesófilos aeróbios manteve-se dentro do exigido pela legislação para este critério, que é de $1,5 \times 105 \mathrm{UFC} / \mathrm{ml}$ para o produto pasteurizado e para o acidificado. A contagem de bolores e leveduras para os tratamentos b e c não ultrapassou os 103 UFC/ $\mathrm{ml}$, enquanto que para o tratamento a nos 14 dias já estava em $106 \mathrm{UFC} / \mathrm{ml}$. Apesar de não existir requisitos legais para este parâmetro, percebe-se que a bebida láctea apenas pasteurizada não apresentou estabilidade durante o período de avaliação, enquanto que nos produtos em que ocorreram modificação de $\mathrm{pH}$ e acidez a estabilidade foi mantida.

Não ocorreu crescimento de coliformes a 35 e a 45드, no teste presuntivo, também para as amostras mais ácidas. Já no produto pasteurizado, aos 14 dias de armazenamento a contagem para coliformes a $35 \circ \mathrm{C}$ era de $>1100 \mathrm{NMP} / \mathrm{ml}$, e de coliformes a $45^{\circ} \mathrm{C}$, de $460 \mathrm{NMP} / \mathrm{ml}$, sendo o padrão exigido pela legislação de $5 \mathrm{NMP} / \mathrm{ml}$ e $2 \mathrm{NMP} / \mathrm{ml}$, respectivamente, comprovando, dessa forma, que a estabilidade da bebida láctea apenas pasteurizada é de 7 dias, enquanto as demais se mantiveram estáveis durante o período analisado.

Em relação à estabilidade físico-química, avaliou-se durante os 35 dias de armazenamento o pH e a acidez titulável. Os resultados estão apresentados nos Quadros 3 e 4 . Observa-se que para as formulações b e c os parâmetros permaneceram estáveis ao longo do tempo de armazenamento analisados, apresentando pequenas variações, enquanto que para a formulação a foi verificada variação e acidificação, complementando as informações microbiológicas que comprovam a inadequação deste produto por mais de 7 dias.

Quadro 3: Médias de pH obtidas durante o período de armazenamento

\begin{tabular}{|c|c|c|c|c|c|}
\hline \multicolumn{6}{|c|}{$\mathrm{pH}$} \\
\hline \multicolumn{7}{|c|}{ Tempo de armazenamento (dias) } \\
\hline Formulações & 1 & 7 & 14 & 21 & 35 \\
a & 6,66 & 6,67 & 6,58 & 6,45 & 6,36 \\
b & 4,02 & 4,03 & 4,03 & 4,05 & 4,07 \\
c & 4,71 & 4,70 & 4,73 & 4,76 & 4,75 \\
\hline
\end{tabular}

Fonte: Dos autores (2012)

Quadro 4: Médias da acides titulável obtidas durante o período de armazenamento

\begin{tabular}{|c|c|c|c|c|c|}
\hline \multicolumn{6}{|c|}{ Acidez Titulável (\% ácido lático) } \\
\hline \multicolumn{7}{|c|}{ Tempo de armazenamento (dias) } \\
\hline Formulações & 1 & 7 & 14 & 21 & 35 \\
a & 0,17 & 0,18 & 0,20 & 0,22 & 0,25 \\
b & 0,76 & 0,77 & 0,76 & 0,78 & 0,79 \\
c & 0,70 & 0,71 & 0,72 & 0,72 & 0,73 \\
\hline
\end{tabular}

Fonte: Dos autores 
Esses resultados são compreensíveis, pois o produto a, devido à embalagem utilizada não oferecer maior proteção, apenas a pasteurização não é suficiente para manter a estabilidade durante muito tempo. Já que nos demais casos o tratamento térmico realizado foi o mesmo e devido à diminuição do $\mathrm{pH}$ e da acidez, o prazo de validade foi estendido.

Considerando que o produto apenas pasteurizado apresentou a melhor aceitação perante o consumidor, poderia ser produzido pelo processo UAT e envasado em embalagens que oferecessem melhor proteção, a fim de prolongar a vida de prateleira do mesmo, mantendo-se as características sensoriais que foram apreciadas pelos provadores.

\section{CONSIDERAÇÕES FINAIS}

Verificou-se que as formulações de bebidas lácteas com amaranto apresentaram teor proteico acima de $2,5 \%$, sendo maior do que o normalmente encontrado neste tipo de produto, consequência da adição do amaranto nas formulações testadas. As demais características físico-químicas ficaram dentro do normal encontrado em bebidas lácteas.

A maior aceitação pelos provadores foi da bebida láctea apenas pasteurizada, com mais de $97 \%$ de avaliações positivas, seguida pela bebida acidificada e, por último, a fermentada, demonstrando que os consumidores preferem o produto sem modificação do $\mathrm{pH}$ e acidez.

Em relação à vida de prateleira, as bebidas lácteas acidificadas e fermentadas apresentaram estabilidade durante os 35 dias de armazenamento, enquanto que a pasteurizada apenas esteve estável nos primeiros 7 dias, tanto nos parâmetros microbiológicos o que prova que a modificação da acidez do produto prolonga a sua vida de prateleira.

Portanto, o uso do amaranto foi importante para aumentar o teor proteico do produto, e a análise sensorial demonstrou a boa aceitação dessa complementação, juntamente com o sabor chocolate branco. No entanto, considerando-se que a bebida láctea pasteurizada foi a mais aceita sensorialmente e não apresentou boa estabilidade, recomenda-se a modificação do processo para o UAT e o envase em embalagens que garantam uma maior vida de prateleira. 


\title{
DRINK MILK WITH AMARANTO
}

\begin{abstract}
Whey is a residue from the production of cheese and often a problem for the dairy industry, it presents potential polluter. The use of whey in milk drinks is presented as an alternative to enjoy the nutritional potential of this residue. Amaranth is a pseudocereal little known in Brazil, however, has high biological value proteins. The objective of this work was to develop a milky drink with white chocolate flavored amaranth in three different formulations: pasteurized, acidified and fermented, performing physicalchemical, sensory analysis and determination of shelf life. The protein content of the three formulations was above $2.5 \%$, higher than that normally found in milk drinks, other physical and chemical parameters were within expectations. In sensory analysis, drinking pasteurized milk showed more than $97 \%$ of positive evaluations when acidified showed $88 \%$ and fermented $84 \%$; tasters showed good acceptance by the addition of amaranth and taste of white chocolate. Shelf life demonstrated stability within 35 days of storage of the acidified and fermented beverage while only pasteurized presented durability of 7 days, and the protein content was increased due to the addition of amaranth and considering further that the preferred formulation was the pasteurized one and that it had low storage stability, it is recommended to use the UAT process for the preparation of this product.
\end{abstract}

Keywords: Whey. Pseudocereal. Protein content.

\section{REFERÊNCIAS}

AMAYA-FRAFAN, Jaime; MARCÍLIO, Roberto; SPEHAR, Carlos Roberto. Deveria o Brasil investir em grãos para a sua alimentação?: a proposta do amaranto (Amaranthus sp.). Segurança Alimentar e Nutricional, Campinas, SP, v.12, n.1, p. 47-56, 2005. Disponível em: <http://www.unicamp.br/nepa/arquivo_san/A_proposta_do_Amaranto.pdf>.

Acesso em: 03 dez .2011.

ANTUNES, Aloísio José. Funcionalidade de proteínas do soro de leite bovino. Barueri, SP: Manole, 2003. 
BRASIL, Decreto n. 30.691, de 29 de março de 1952. Aprova o novo regulamento da inspeção industrial e sanitária de produtos de origem animal. Ministério da Agricultura Pecuária e Abastecimento. Diário Oficial da União, Rio de Janeiro, 29 mar. 1952. Disponível em: <http://www.planalto.gov.br/ccivil_03/decreto/1950-1969/ D30691compilado.htm>. Acesso em: 11 jan. 2013.

BRASIL. Ministério da Agricultura. Regulamento da inspeção industrial e sanitária de produtos de origem animal. (aprovado pelo Decreto 30.6912 de 29/03/1952 e alterado pelo Decreto 1255 de 25/06/1962). Brasilia, 1980.

Instrução Normativa n. 16, de 23 de agosto de 2005. Aprova o regulamento técnico de identidade e qualidade de bebida láctea. Ministério da Agricultura, Pecuária e Abastecimento. Diário Oficial da União. Brasília, DF: 24 ago. 2005. Disponível em: <http://extranet.agricultura.gov.br/sislegis-consulta/consultarLegislacao.do?operacao= visualizar\&id=12792>. Acesso em: 11 jan. 2013.

. Instrução Normativa n. 62, de 26 de agosto de 2003. Oficializa os métodos analíticos oficiais para análises microbiológicas para controle de produtos de origem animal e água. Ministério da Agricultura, Pecuária e Abastecimento. Diário Oficial da União, Brasília, DF: 19 set. 2003.

Instrução Normativa n. 68, de 12 de dezembro de 2006. Oficializa os Métodos Analíticos Oficiais Físico-Químicos, para Controle de Leite e Produtos Lácteos, em conformidade com o anexo desta Instrução Normativa, determinando que sejam utilizados nos Laboratórios Nacionais Agropecuários. Ministério da Agricultura, Pecuária e Abastecimento Diário Oficial da União. Brasília, DF: 14 dez. 2006. Disponível em: <http://extranet.agricultura.gov.br/sislegis-consulta/consultarLegislacao.do?opera cao=visualizar\&id=17472>. Acesso em: 13 jan. 2013.

FONTAN, G.C.R. Influência do uso de espessantes nas características sensoriais e físico-químicas de bebida láctea com polpa de umbu. 2008. 57 f. Dissertação (Mestrado em Engenharia de Processos de Alimentos) - Universidade Estadual do Sudoeste da Bahia, Itapetininga, 2008.

GANDHI, D.N.; PATEL, R.S. Technology and keping quality of fermented whey concentrate. Cultured Dairy Products Journal, v. 29, n.1, p.25-27, 1994.

KEMPEKA, A. P et al. Formulação de bebida láctea fermentada sabor pêssego utilizando substratos alternativos e cultura probiótica. Ciência e Tecnologia de Alimentos. Campinas, SP: n. 28 p. 170-177, dez. 2008. Disponível em: <http://www.scielo.br/pdf/ cta/v28s0/27.pdf>. Acesso em: 13 jan. 2013. 
LUPATINI, Eroni. Quinoa e amaranto: alimentos de ouro. [S.I.: s.n.], 2009. Disponível em: <http://www.eronilupatini.com/artigos/art/36\%20-\%20QUINOA\%20E\%20 AMARANTO.pdf>. Acesso em: 05 dez. 2011.

OLIVEIRA, M. N. Tecnologia de produtos lácteos funcionais. São Paulo: Atheneu Editora, 2009.

SANTOS, C.T et al. Influência da concentração de soro na aceitação sensorial de bebida láctea fermentada com polpa de manga. Alim. Nutr. Araraquara, v. 19, n.1, p. 5560, jan/mar. 2008. Disponível em: < http://serv-bib.fcfar.unesp.br/seer/index.php/ alimentos/article/viewFile/199/204>. Acesso em: 13 jan. 2013.

SANTOS, P. G dos; COSTA, D. M. A da. Vantagens do cultivo do amaranto. In: CONGRESSO DE PESQUISA E INOVAÇÃO DA REDE NORTE NORDESTE DE EDUCAÇÃO TECNOLÓGICA, 2., 2007, João Pessoa, PB. Anais... João Pessoa, PB: [s.n.], 2007. Disponível em: < http://pt.scribd.com/doc/38681162/A-Mar-an-To>. Acesso em: 13 jan. 2013.

THAMER, K.G.; PENNA, A.L.B. Caracterização de bebidas lácteas funcionais fermentadas por probióticos e acrescidas de prebióticos. Ciência e Tecnologia de Alimentos.

Campinas, SP: v. 26, n.3, p. 589-595, jul./set. 2006. Disponível em: <http://www.scielo. $\mathrm{br} / \mathrm{pdf} / \mathrm{cta} / \mathrm{v} 26 \mathrm{n} 3 / 31761>$. Acesso em: 13 jan. 2013.

TRONCO, V.M. Manual para inspeção da qualidade do leite. 4 ed. Santa Maria: Ed. UFSM, 2010.

ZACARCHENCO, P. B et al. Soro de leite: de problema ambiental a solução para tratamento de doenças. Leites e Derivados, São Paulo, v. 17, n. 106, p. 138-148, jul. 2008. 


\section{SOBRE OS AUTORES}
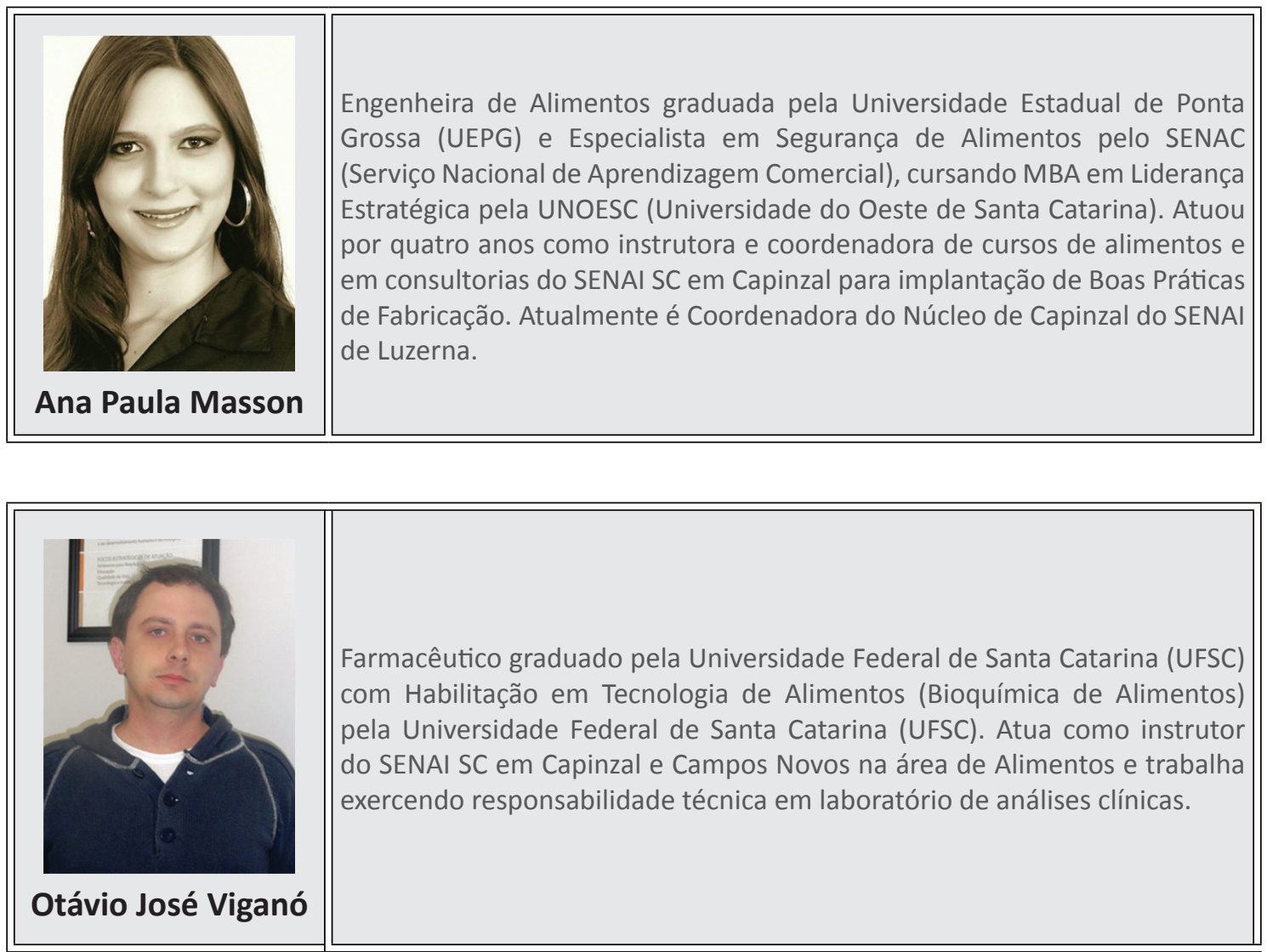

Originais recebidos em: 31/01/2013

Texto aprovado em: 15/10/2013 